\title{
Видовий склад патоценозу та вплив фунгіцидів на збудників хвороб багаторічної деревини
}

\author{
Олександр М. Слюсаренко ${ }^{1}$, Катерина А. Шматковська \\ ${ }^{1}$ Ботанічний сад ОНУ ім. I. I. Мечникова, МОН України, м. Одеса, Україна, e-mail: slyusarenko@onu.edu.ua \\ ORCID ID0000-0001-6287-3243 \\ ${ }^{2}$ Наџіональний науковий џентр «Інститут виноградарства і виноробства ім. В. Є. Таїрова» НААН України, Одеса, Україна \\ ORCID ID0000-0002-3884-7595
}

\section{Реферат.}

Mema. Дослідити мікофлору багаторічної деревини виноградних насаджень Північного Причорномор'я та з'ясувати вплив фунгіџидів на збудників хвороб деревини. Методи. Вивчення видового складу мікофлори винограду проводили з використанням загальноприйнятих методів мікологічних і фітопатологічних досліджень. Ізоляти виділяли з багаторічних органів виноградної рослини з ознаками патологічних змін у чисту культуру і проводили ідентифікаџію збудників хвороб за морфологічними ознаками. Токсикологічну дію фунгіџидів визначали додаванням ї робочих розчинів у живильне середовише чашок Петрі та додаванням до суспензії спор збудника. Розмір колоній та схожість спор визначали за загальноприйнятими методиками мікологічних досліджень. Результати. Серед компонентів мікофлори було виділено і ідентифіковано 18 видів грибів, шо спричинюють хвороби багаторічних органів рослин, збудників неспеџифічних мікозів та інших представників мікобіоти з різних систематичних груп та класів. У лабораторних умовах досліджено вплив фунгіџидів на розвиток збудників хвороб багаторічної деревини Eutypa lata (Pers: Fr.) Tul. та Phomopsis viticola Sacc. 3' ясовано, шо робочі розчини фунгіџидів у живильному середовиші викликають депресію розвитку колоній Eutypa lata (Pers: Fr.) Tul. та зменшують показник проростання спор Phomopsis viticola Sacc. Висновки. Було вивчено склад патогенів лози виноградних насаджень Північного Причорномор'я, особливості їх культивування на живильних середовищах та морфологічні ознаки. Виявлено 18 видів, шо спричинюють хвороби багаторічної деревини винограду і відносяться до різних систематичних груп та класів. Дослідження збудників Eutypa lata (Pers: Fr.) Tul. та Phomopsis viticola Sacc. в умовах живильного середовища підтвердили високу інгібуючу дію фунгіџидів на іх розвиток.

Ключові слова: видовий склад мікофлори, ідентифікаџія, особливості культивування, живильне середовище, фунгіџиди.

\section{Species Composition of Patocenose and Fungicides Influence on The Perennial Wood Pathogens}

\author{
Oleksandr M. Sliusarenko ${ }^{1}$, Kateryna A. Shmatkovska ${ }^{2}$ \\ ${ }^{1}$ Botanical Garden of ONU them. I. I. Mechnikov, Ministry of Education and Science of Ukraine, Odessa, Ukraine, \\ e-mail: slyusarenko@onu.edu.ua \\ ORCID ID0000-0001-6287-3243 \\ ${ }^{2}$ National Scientific Center “Institute of Viticulture and Wine. V. Ye. Tairova »NAAS of Ukraine, Odessa, Ukraine \\ ORCID ID0000-0002-3884-7595
}

\section{Abstract.}

Aims. To study the pathogenic mycoflora of vineyard's perennial wood of the Northern Black Sea Region and investigate the fungicidal influence on pathogens of wood diseases. Methods. The study of the species composition of the grapes mycoflora had been conducted using common methods of mycological and phytopathological researches. Isolates had been 
selected from multiple organs of vine plants with signs of pathological changes in pure culture and made identification of the diseases pathogens by morphological features. Toxicological effect of fungicides had been determined by the adding of their working solutions in the nutrient medium of Petri dishes and the adding of a pathogen spores to the suspension. The size of the colonies and the similarity of the spores had been determined by the generally accepted methods of mycological research. Results. Among the components of the mycoflora, 18 species of fungi causing diseases of perennial organs of plants, pathogens of nonspecific mycoses and other representatives of mikobioti from different systematic groups and classes had been identified. In the laboratory, the influence of fungicides on the development of perennial diseases pathogens - Eutypa lata (Pers: Fr.) Tul. and Phomopsis viticola Sacc. had been studied. It was found that working solutions of fungicides in the nutrient medium cause depression of the development of the Eutypa lata colonies and reduce the germination rate of the Phomopsis viticola spore. Conclusions. The composition of pathogens of vines of the Northern Black Sea region had been studied. The features of their cultivation on nutrient media and morphological features had been revealed. 18 types of pathogens, which cause the perennial vine wood diseases and belong to different systematic groups and classes had been identified. The study of Eutypa lata and Phomopsis viticola pathogens in conditions of nutrient medium proved a high inhibitory effect of fungicides on their development.

Key words: species composition of mycoflora, identification, features of cultivation, nutrient medium, fungicides.

Вступ/Introduction. Мікобіота виноградної рослини надзвичайно різноманітна і з часом перетерплює значних змін. Всебічне вивчення збудників хвороб, ї біологї, закономірностей розвитку і впливу на виноградну рослину в різних агрокліматичних умовах вирощування є тим науковим фундаментом, що надає можливість обгрунтовано впроваджувати систему інтегрованого управління фітосанітарним станом агроценозів (Tribel' et al., 2010).

Слід зазначити, шо до числа шкідливих агентів, які знижують кількість та якість продукџї виноградарства, належать не тільки облігатні паразити, шо розвиваються виключно на живих тканинах рослини-хазяїна і відмирають разом з ними (Zheldakova \& Mjamin, 2006). Більшість патогенних для винограду організмів є або напівпаразити або напівсапрофіти. Останні часто є супутниками облігатних паразитів та комах-шкідників і настільки потужно впливають на перебіг хвороби, що кущі або різко знижують урожайність, або зовсім гинуть. Багато збудників хвороб не є спеџифічними паразитами тільки виноградної рослини. Вони мають властивість розвиватись на ряді рослин, сусідство з якими може сприяти захворюванню винограду (Kostjuk, 1949).

Таким чином, розвиваючись виключно на виноградній лозі або й на інших різноманітних живих рослинах та рослинних рештках і руйнуючи їх, гриби можуть викликати великі втрати корисних рослинних продуктів та чинити шкідливий вплив на культуру винограду. Тому метою нашої роботи було з'ясування видового складу патоџенозу виноградної рослини, виділення збудників хвороб багаторічної деревини та визначення токсичності фунгіџидів щодо збудників џих хвороб.

Матеріали і методи/Materials and methodology. Для з'ясування видового складу мікофлори багаторічної деревини винограду проводили відбір ізолятів з визначенням їх видової приналежності. Для діагностики патогену використовували методи мікологічних посівів на тверде агаризоване живильне середовище. Ізоляти виділяли з різних органів виноградної лози з ознаками патологічних змін (деревини, гребнів, грон) у чисту культуру за загальноприйнятою методикою. Після пророџування грибів виготовляли препарати, які аналізували під мікроскопом Біомед-1 при різному збільшенні. Гриби ідентифікували за морфологічними ознаками (морфологія спор, спороносії, та ін.), користуючись визначником П. Н. Костюка «Шкідлива флора виноградної лози» (Kostjuk, 1949) та визначником Н.М. Підопличка «Гриби - паразити культурних рослин» (Pidoplichko, 1977; Pidoplichko, 1977; Pidoplichko, 1978).

Виділені збудники висівали в чашки Петрі на агаризоване середовище та культивували в термостаті за температури $22^{\circ} \mathrm{C}$.

Сусло - агар виготовляли за методикою Білайя (Bilaj et al., 1973).

Склад: агар-агар - 20 г, пивне сусло - 1000 мл. Приготування середовища: до 1 літру не охмеленого пивного сусла додавали 20 г агар-агару, розчиняли поступово при нагріванні. Стерилізували в автоклаві при 0,5 атм. 30 хвилин.

Методами мікологічного аналізу досліджено параметри розвитку Eutypa lata (Pers: Fr.) Tul. та 
Phomopsis viticola Sacc. на твердому агаризованому середовищі (Bilaj et al., 1988).

Токсикологічну оџінку фунгіџидів з різною діючою речовиною, шо включені до «Переліку пестиџидів і агрохімікатів, дозволених до використання в Україні» (Perelik pestytsydiv... 2008.), з комплексною дією на збудників хвороб винограду грибної етіологї проводили в лабораторних умовах за наступною схемою:

Варіанти досліду:

1. Контроль (дистильована вода);

2. Пропінеб;

3. Азоксистробін (250 г/ );

4. Каптан (500 г/кг);

5. Манкоџеб (640 г/кг) + металаксил $(40$ г/кг);

6. Триадименол $(20$ г/кг) + фолпет $(700$ г/кг).

Для визначення токсикологічної дії фунгіџидів на Eutypa lata (Pers: Fr.) Tul. у живильне середовище чашок Петрі додавали робочі розчини дослідних фунгіџидів у конџентраџіях рекомендованих виробником для створення робочої рідини. Шоденні спостереження за колоніями вели візуально. Розмір колоній визначали за середніми значеннями трьох вимірів їх діаметрів. (Bilaj et al., 1973; Bilaj et al., 1988).

$\mathrm{Y}$ лабораторних умовах визначали токсикологічну дію фунгіџидів на Phomopsis viticola Sacc. Для џього робочу рідину препаратів наносили дозатором на предметні скельџя. Після підсихання рідини на скельџя додавали суспензію спор збудника чорної плямистості винограду - Phomopsis viticola Sacc., які пророџували при температурі $25-26^{\circ} \mathrm{C}$ у вологій камері. Контролем в досліді була спорова суспензія без внесення препарату.
Облік пророслих спор проводили через 18-20 годин за допомогою мікроскопу Біомед- 1 , підраховуючи кількість пророслих спор із ста. Пророслою вважали спору, росток якої за розміром був більше половини її діаметра. Після џього розраховували відсоток пророслих спор згідно методичних рекомендаџій B. I. Білайя (Bilaj et al., 1973) за формулою:

$$
\mathrm{T}=\left(\Pi_{\kappa}-\Pi_{д}\right) / \Pi_{\kappa} \cdot 100 \text {, }
$$

де: Т\% - проростання спор; Пк - відсоток пророслих спор в контролі; Пд - відсоток пророслих спор в дослідному варіанті.

Результати та обговорення/Results and Discussion. На першому етапі роботи нами було вивчено видовий склад патогенної мікофлори багаторічної деревини винограду.

На деревині кушів винограду виявлені 18 видів збудників хвороб багаторічних органів рослин, серед них - Botrytis cinerea Pers. (сіра гниль), Sphaeropsis malorum Peck. (чорний рак), Phomopsis viticola Sacc. (чорна плямистість, екскоріоз), Eutypa lata (Pers: Fr.) Tul. (еутіпоз), які вважають збудниками хвороб всихання виноградної деревини та збудники неспеџифічних мікозів - Penicillium rugulosum Thom., Alternaria vitis Nees., Aspergillus niger Thieg. Також на поверхні агаризованого середовища було виділено колонії різноманітного комплексу грибів - Mucor racemosus Fr., Mucor circinelloides Van Tieghem, Monilia fructigena Pers., Pythium vitis Serbinov, Macrosporium vitis Sorok., Trichothecium roseum (Pers.) Link та інших видів. Дані вивчення особливостей морфології грибів зведені та представлені в таблиці (табл. 1).

Таблиџя 1. Культуральні особливості мікофлори багаторічної деревини виноградних насаджень Північного Причорномор'я

Table 1. Crops features of mycoflora of vine perennial wood of the Northern Black Sea region

\begin{tabular}{|c|c|c|}
\hline Збудник/Pathogen & $\begin{array}{l}\text { Культуральні ознаки колонії } \\
\text { Crops features of the colony }\end{array}$ & $\begin{array}{l}\text { Особливості морфології } \\
\text { Features of morphology }\end{array}$ \\
\hline Mucor racemosus Fres. & $\begin{array}{l}\text { В культурах утворює колонії білого або } \\
\text { жовто-білого кольору }\end{array}$ & Спорангієносџі 8-20 мкм товщини \\
\hline $\begin{array}{l}\text { Mucor circinelloides } \\
\text { Tieghem. }\end{array}$ & $\begin{array}{l}\text { Колонії блідо сірі, з бурим відтінком, } \\
0,3-1 \text { см заввишки, складаються з двох } \\
\text { ярусів }\end{array}$ & $\begin{array}{l}\text { Спорангієносџі до } 20 \text {-го порядку дуже } \\
\text { сильно симподіально розгалужені, не } \\
\text { фото тропічні. Спорангї гігроскопічні, } \\
70-100 \text { мкм }\end{array}$ \\
\hline Aspergillus niger Thieg. & $\begin{array}{l}\text { Гриб утворює пухкий міџелій. Конідіє- } \\
\text { носна зона чорного кольору }\end{array}$ & $\begin{array}{l}\text { Стерігми, } 20 \times 7 \text { мкм, } 7 \times 3 \text { мкм. Конідії } \\
\text { кулясті, } 3 \text { мікр. зібрані в ланџюги }\end{array}$ \\
\hline
\end{tabular}




\begin{tabular}{|c|c|c|}
\hline 1 & 2 & 3 \\
\hline $\begin{array}{l}\text { Penicillium rugulosum } \\
\text { Thom. }\end{array}$ & $\begin{array}{l}\text { Пліснява спочатку жовто-зелена з } \\
\text { жовто-білим окаймленням, на поверхні з } \\
\text { дрібної безкольоровою крапчатістю }\end{array}$ & $\begin{array}{l}\text { Конідієносџі гладеньки, 3-4 мкм товщи- } \\
\text { ни, несуть на собі двоярусні кисточки. Ко- } \\
\text { нідії еліпсоідальні, на кінџі трохи звужені, } \\
\text { 3-4×2,5-3,5 мікр., дрібнобородавчасті }\end{array}$ \\
\hline Pythium vitis Serbinov & Грибниџя ніжна, білого кольору & $\begin{array}{l}\text { Гіфи в діаметрі 9,22-16,4 мікр. Антерідій } \\
\text { (чолов. зародок) розм. 12-28×6,5 мкм } \\
\text { Оогоній (жіночій зародок) 26-65 мкм } \\
\text { Ооспора (плодове тіло) має гладеньку } \\
\text { поверхню або з виступами, безкольорова, } \\
\text { діаметром 12,28-25 мкм }\end{array}$ \\
\hline Alternaria vitis $\mathrm{Cav}$. & $\begin{array}{l}\text { Сіро-фіолетовий або олівкового кольору } \\
\text { бархатистий наліт конідіального спороно- } \\
\text { шення грибка }\end{array}$ & $\begin{array}{l}\text { Конідієносџі поодинокі 150×3,5 6,5 мкм. } \\
\text { Спори грушеподібної форми багатоклітин- } \\
\text { ні з перегородками, олівкового кольору, } \\
\text { 150×3,5-6,5 мкм }\end{array}$ \\
\hline Macrosporium vitis Sorok. & $\begin{array}{l}\text { Утворює густий зеленувато-оливковий } \\
\text { наліт }\end{array}$ & $\begin{array}{l}\text { Спори мають перепони, брудно коричневі, } \\
\text { розм. 28-30 мкм довж. та } 15 \text { мкм товШ. }\end{array}$ \\
\hline $\begin{array}{l}\text { Trichothecium roseum } \\
\text { (Pers.) Link. }\end{array}$ & Конідієносна зона рожевого кольору & $\begin{array}{l}\text { Конідії в ланџюжках по 3-4, кулясті, } \\
\text { брудного коричневого кольору, 5-8 мкм }\end{array}$ \\
\hline Monilia fructigena Pers. & $\begin{array}{l}\text { Спороношення грибка спочатку біле, по- } \\
\text { тім набуває жовтого кольору, а під кінеџь } \\
\text { стає червоним або коричневим }\end{array}$ & $\begin{array}{l}\text { Конідії еліпсоїдальні, 20-24 мкм товщ., } \\
\text { прозорі }\end{array}$ \\
\hline Botrytis cinerea Pers. & $\begin{array}{l}\text { Конідіальна стадія характеризується } \\
\text { сірим нальотом. Апотеџї бурого кольору }\end{array}$ & $\begin{array}{l}\text { Конідієносџі деревовидні розгалужені. } \\
\text { Спори одноклітинні, безкольорові або сірі, } \\
\text { еліпсоїдальні, розміром 10-14×7-9 мкм }\end{array}$ \\
\hline Phomopsis viticola Sacc. & $\begin{array}{l}\text { Для конідіальної стадії характерне утво- } \\
\text { рення слабко пухкого, розгалуженого, } \\
\text { білого міџелію }\end{array}$ & $\begin{array}{l}\text { Утворює пікніди з жовтуватими } \alpha \text { - та } \beta \text { - } \\
\text { спорами }\end{array}$ \\
\hline Sphaeropsis malorum Peck. & Міџелій міџний, темно-сірий & Повітряні гіфи з перетинками \\
\hline Tubercularia vulgaris Tode. & $\begin{array}{l}\text { Рожево-червоні бугорки, які уявляють } \\
\text { собою стромоподібні ложа, заповненні } \\
\text { дрібними конідіями }\end{array}$ & $\begin{array}{l}\text { Конідії 5-8×1-3 мкм, кулясті або гілко } \\
\text { подібні, безкольорові, одноклітинні }\end{array}$ \\
\hline Fusarium viticolum Thuem. & $\begin{array}{l}\text { Міџелій гриба повітряний рожево-жов- } \\
\text { того кольору }\end{array}$ & $\begin{array}{l}\text { Конідії веретено або серпоподібні з 1-4 } \\
\text { перетинками. Розмір 37,5×4 мкм }\end{array}$ \\
\hline $\begin{array}{l}\text { Guignardia Bidwellii (Ell.) } \\
\text { Vial. Et Rav. }\end{array}$ & $\begin{array}{l}\text { В культурах утворює колонії білого } \\
\text { кольору }\end{array}$ & $\begin{array}{l}\text { Мікро- та макроконідії кулясті, мають } \\
\text { товсту оболонку та вихідні отвори для ви- } \\
\text { кидання спор }\end{array}$ \\
\hline $\begin{array}{l}\text { Verticillium stilboideum } \\
\text { Sacc. }\end{array}$ & $\begin{array}{l}\text { Грибниџя повзуча, малорозвинена бруд- } \\
\text { но-сірого кольору }\end{array}$ & $\begin{array}{l}\text { Конідієносџі вертикальні, џільно роз- } \\
\text { галужені з гілочками розміром до 0,75 мм } \\
\text { довжини. Конідії яйџеподібної або еліп- } \\
\text { соїдальної форми, безкольорові, з двома } \\
\text { краплями олї, 6-7 мкм довжини та } 3 \text { мкм } \\
\text { товщини }\end{array}$ \\
\hline $\begin{array}{l}\text { Eutypa lata (Pers:Fr.) Tul. } \\
\text { \& C. Tul. (Eutypa armenia- } \\
\text { cae Hansf. \& Carter) }\end{array}$ & Міџелій міџний, білий & $\begin{array}{l}\text { Повітряні гіфи з перетинками. Пікніди } \\
\text { темні, з жовтуватим восковим вмістом }\end{array}$ \\
\hline Базідіоміџети & $\begin{array}{l}\text { Мiџелій тонкий, пухкий, коричневого або } \\
\text { зеленого кольору, без плодоношення }\end{array}$ & Не утворює плодових тіл \\
\hline
\end{tabular}


На другому етапі в лабораторних умовах було досліджено вплив препаратів фунгідидної групи з різної діючою речовиною на збудника еутипозу - Eutypa lata (Pers: Fr.) Tul. та збудника чорної плямистості Phomopsis viticola Sacc.

Характерно, що при додаванні до живильного середовища фунгіџидів, спостерігали депресію розвитку колоній. На рис. 1 показано, шо розмір колоній Eutypa lata у контрольному варіанті без внесення фунгіџиду варіює в межах 60-70 мм. 3 додаванням фунгіџидів з різною діючою речовиною до живильного середовиша ріст міџелію значно зменшується. При додаванні до середовища фунгіџидів з діючою речовиною азоксистробін, пропінеб, каптан розмір колоній Eutypa lata зменшується в діаметрі до 0-10 мм. При додаванні до живильного середовиша фунгіџидів з діючою речовиною триадименол + фолпет та манкоџеб + металаксил діаметр колоній становив 10-20 мм.

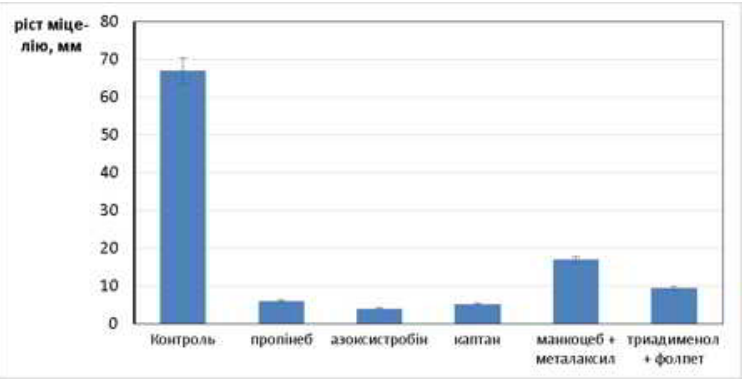

Рисунок 1. Вплив різних фунгіџидів на ріст міџелію збудника еутипозу винограду (Eutypa lata (Pers: Fr.) Tul.), ННЦ «ВіВ ім. В. Є. Таїрова»

Figure 1. Influence of various fungicides on growth of mycelia of the pathogen of grape eutiposus (Eutypa lata (Pers: Fr.) Tul.), NSC "IViV them. V.E. Tairovo"

Лабораторні випробування препаратів фунгіџидної групи з різною діючою речовиною на розвиток спор збуднику чорної плямистості дозволили встановити ix високу ефективність. У контрольному варіанті проростання спор Phomopsis viticola було на рівні 65-75\%. При додаванні до живильного середовища фунгіџидів з різною діючою речовиною спостерігалося зменшення показника проростання спор збудника чорної плямистості до 5-15\% (рис. 2).

Як зазначалось виџе, мікофлора патогенних видів грибів з часом зазнає значних змін, на шо безумовно впливає й місџе вирошування винограду. Џей факт підтверджується закордонними дослідами етіології захворювань, які широко висвітлюють дане питання.

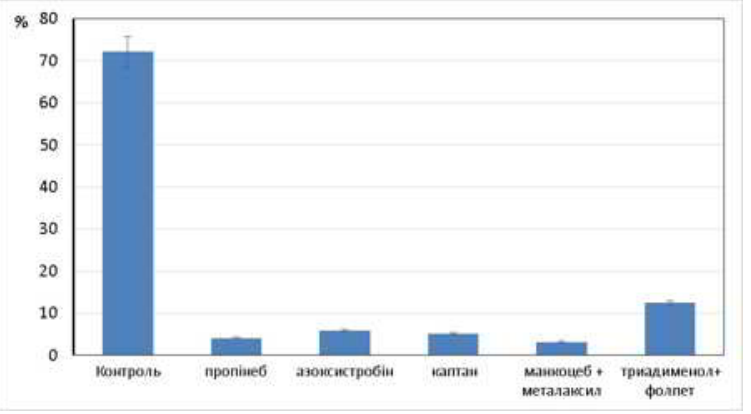

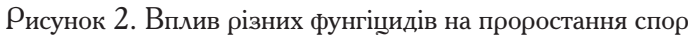
збудника чорної плямистості винограду (Phomopsis viticola Sacc.), \%, НHЦ «IBiB ім. В. Є. Таїрова»

Figure 2. Influence of various fungicides on germination of spores of the black spotted grapevine (Phomopsis viticola Sacc.), \%, NSC "IViV them. V.E. Tairovo "

При проведенні обстежень виноградних насаджень Португалії було виявлено хворобу багаторічної деревини чорне відмирання рукавів (збудники роду Botryosphaeria), ознаки якої дуже близькі до ознак ураження винограду еутипозом. Автори описують џих збудників як умовно-патогенні мікроорганізми, шо спричинюють хвороби у рослин з слабким імунітетом (Phillips, 1998; Phillips, 2002). Зразки деревини взятих з пригнічених, відсталих у рості кущів показали наявність патогенів Cylindrocarpon liriodendri MacDon. i Butler, C. destructans (Zinsm.) Scholten та C. macrodidymum Schroers. Halleen et $\mathrm{al}$, які є збудниками чорної ніжки (Halleen, 2003; Halleen, 2006; Halleen, 2006). Џих патогенів виявляють практично у всіх виноградарських регіонах світу. Dubrovsky S. та Fabritius A. (Dubrowski \& Fabritius, 2007) проводили дослідження зразків саджаншів основних розсадників винограду Каліфорнії (США). З'ясовано, шо Cylindrocarpon liriodendri MacDon. i Butler $€$ найбільш розповсюдженим збудником хвороби чорної ніжки, наявність зафіксовано у $26 \%$ зразків. Phaeoacremonium aleophilum (Pal) діагностовано у $19 \%$ та Phaeomoniella chlamydospora (Pch) у 4\% зразків саджанџів.

У сучасному виноградарстві основний метод обмеження шкідливості збудників хвороб грибної етіології є застосування фунгіџидів. Однак на сьогодні у «Переліку пестиџидів і агрохімікатів, дозволених для використання в Україні» не зареєстровано препаратів від хвороб деревини з лікувальною дією шодо збудників ески та еутипозу, які 6 були здатні повністю припинити розвиток хвороби та вилікувати рослину. Проблема в тому, шо місџе існування патогенів, які викликають џі хвороби, в клітинах судинної 
системи, яка захищена покривними тканинами рослин від зовнішнього впливу. Так, П. Віала ше на початку XX століття виявив інгібуючу дію арсеніту натрію на розвиток збудників ески. Сполуки арсеніту натрію пригнічували їх розвиток і перешкоджали зараженню здорових рослин. Через високу токсичність діючої речовини, канџерогенний вплив на організм людини, арсеніти були заборонені до застосування у більшості країн світу. Так, наприклад, у Німеччині введено сувору заборону на застосування подібних препаратів (Mugnai et al., 1999).

За даними P. Rolshausen та ін. (Rolshausen et al., 2010) інгібуючу дію на збудників хвороб багаторічної деревини проявляють й фунгіџиди, що використовують у захисті винограду від сезонних захворювань. Авторами досліджено вплив фунгіџидів з діючою речовиною тіофанат метіл (1\%), $5 \%$ борної кислоти, стробілурин (1\%) на розвиток збудників Eutypa lata (Pers: Fr.) Tul. \& C. Tul. (Eutypa armeniacae Hansf. \& Carter), Botryosphaeria dothidea (Moug. ex Fr.) Ces. \& De Not, Diplodia seriata De Not, Lasodiplodia theobromae (Pat.) Griffon \& Maubl., Phaeomoniella chlamydospora (Pch), Pleurostomophora richardsiae (Nannf. apud Melin \& Nannf.) L. Mostert, W. Gams \& Crous, Togninia minima (Tul. \& C. Tul.) Berl., Dothiorella viticola (A. J. L. Phillips \& J. Luque) та Phaeoacremonium parasiticum (Ajello, Georg \& C. J. K. Wang). 3' ясовано, шо фунгіџиди проявляють вибіркову дію на окремих збудників, найбільшу біологічну активність на комплекс патогенів відзначено при внесенні препарату з діючою речовиною тіофанат метіл.

Можливість контролю збудників хвороб деревини винограду в насадженнях за допомогою фунгіџидів досліджено Dimarco S. та ін. (Di Marco et al., 2000). Авторами показано, шо на виноградниках інфікованих збудниками ески обприскування фунгіџидами з діючими речовинами динитроортокрезол та фосетил алюмінію в період після зимового обрізування кушів до початку розпускання бруньок пригнічує розвиток спороношення патогенів Phaeoacremonium S $\rho$. Встановлено, шо після двох років застосування препаратів відсоток рослин хворих на еску був нижче на оброблених виноградних насадженнях, ніж на насадженнях, на яких не застосовували фунгіџиди.
У практиџі виноградарства України у 80-90-х роках XXI століття широко застосовували препарат з діючою речовиною динитроортокрезол. І. М. Козарєм (Kozar' \& Berezovskaja, 1990) для попередження зараження кущів збудниками хвороб багаторічної деревини винограду було рекомендовано обпри скування кущів препаратом таким чином, щоб його розчини покривали усі поранення рослин спричинені зимовим обрізуванням.

Проте наразі препарат з діючою речовиною динитроортокрезол не включений до «Переліку пестиџидів та агрохімікатів дозволених до використання в Україні» (Perelik pestytsydiv... 2008) у зв'язку з високою токсичністю, канџерогенністю для ссавџів та навколишнього середовища. На сьогодні для захисту винограду від ески та еутипозу у «Переліку пестиџидів і агрохімікатів, дозволених для використання в Україні» зареєстрований препарат хімічної групи стробілурини, шо має досить широкий спектр дії і може використовуватися в якості профілактичного засобу проти хвороб деревини.

Висновки/Conclusions. Проведені нами лабораторні досліди показують, џо призупинення розповсюдження збудників хвороб деревини можливе під час застосування фунгіџидів, з так званим «антиспоруляџійним» ефектом. Препарати, які випробовувались, суттєво відрізнялись за токсичністю і мали вибіркову дію на той чи інший патоген. Отримані в ході досліджень й представлено в статті дані показують, шо додавання фунгіџидів $з$ діючими речовинами азоксистробін, пропінеб, каптан, триадименол + фолпет, манкоџеб + металаксил до живильного середовища пригнічує розвиток колоній збудників еутипозу та чорної плямистості. Схожі токсикологічні дослідження фунгіџидів щодо збудників грибних хвороб були проведені М. Г. Банковською, О. О. Березовською, А. О. Баранеџь (Kozar' \& Berezovskaja, 1990; Berezovs'ka et al., 2006; Baranets' \& Aheieva, 2008).

У зв'язку з тим, шо збудники хвороб багаторічної деревини ведуть прихований спосіб розвитку, застосування фунгіџидів в польових умовах у захисті рослин проти џих захворювань ефективніше при обробџі поранень рослин та пошкоджених ділянок рослин, які слугують брамою інфекџї.

\section{Список посилань/References}

Baranets', L. O., \& Aheieva, O. V. (2008). Toksychnist' funhitsydiv schodo zbudnykiv khvorob vynohradnykh roslyny. Zhurnal Ahrarnyy visnyk Prychornomor'ia. Zbirnyk naukovykh prats'. Odesa; 46. S. 186-188. (in Ukrainian). 
Berezovs'ka, O. O., Kozar, I. M. \& Konstantynova, M. S. (2006) Zakhyst vynohradnykiv vid hrybnykh khvorob. Vynohrad i vyno. № 6. S. 20-21. (in Ukrainian).

Bilaj, V. I., Gvozdjak, R. I., Skripal', I. R. \& Kraev, V. G. (1988). Mikroorganizmy - vozbuditeli boleznej rastenij [Ed.: Bilaj V I]. Kiev: Nauk, dumka. 552 s. (in Russian).

Bilaj, V. I. (1973). Metody jeksperimental'noj mikologii Kiev: Nauk. dumka, 242 s. (in Russian).

Di Marco, S., Mazzullo, A., Calzarano, F. \& A. Cesari. (2000). The control of esca: status and perspectives. Phytopathologia Mediterranea, 39. P. 232-240.

Dubrowski, S. \& Fabritius, A. L. (2007). Occurrence of Cylindrocarpon spp. in nursery grapevines in California. Phytopathologia Mediterranea, 46, P. 84-86. DOI: 10.14601/Phytopathol_Mediterr-1859.

Halleen, F. (2003). Fungi associated with healthy grapevine cuttings in nurseries, with special reference to pathogens involved in the decline of young vines. Journal of Australasian Plant Pathology. 32. P. 47-52. DOI: 10.1071/AP02062.

Halleen, F. (2006). A review of black foot disease of grapevine. Journal of Phytopathologia Mediterranea. 45. P. 55-67. DOI: 10.14601/Phytopathol_Mediterr-1845.

Halleen, F. (2006). Neonectria liriodendri sp. nov., the main causal agent of black foot disease of grapevines. Journal of Studies in Mycology. 55. P. 227-234. DOI: 10.3114/sim.55.1.227.

Kostjuk, P. N. (1949). Vrednaja flora vinogradnoj lozy v Ukrainskoj SSR (opredelitel') Odessa: Odesskoe oblastnoe izdatel'stvo. 184 s. (in Russian).

Kozar', I. M. \& Berezovskaja, E. A. (1990). Zashhita vinograda ot vozbuditelej infekcionnogo usyhanija na Ukraine. Sadovodstvo i vinogradarstvo. № 7. S. 28-30. (in Russian).

Mugnai, L; Graniti, A; \& Surico, G. (1999). Esca (Black Measles) and Brown Wood-Streaking: Two Old and Elusive Diseases of Grapevines. Journal of Plant Disease. 83 (5). P. 404-418.

Perelik pestytsydiv i ahrokhimikativ, dozvolenykh do vykorystannia v Ukraini na 2008 rik.: kataloh 2008. 378 s. (in Ukrainian).

Phillips, A. J. L. (1998). Botryosphaeria dothidea and other fungi associated with excoriose and dieback of grapevines in Portugal. Journal of Phytopathology. 146. P. 327-332.

Phillips, A. J. L. (2002). Botryosphaeria species associated with diseases of grapevines in Portugal. Journal of Phytopathologia Mediterranea. 41. P. 3-18.

Pidoplichko, N. M. (1977). Griby-parazity kul'turnyh rastenij. Opredelitel' v 3-h tomah Київ: Nauk. dumka. T. 1. 295s. (in Russian).

Pidoplichko, N. М. (1977). Griby-parazity kul' turnyh rastenij. Opredelitel' v 3-h tomah. Киӥв: Nauk. dumka. T. 2. 299s. (in Russian).

Pidoplichko, N. M. (1978). Griby-parazity kul' turnyh rastenij. Opredelitel' v 3-h tomah. Київ: Nauk. dumka. T. 3.230 s. (in Russian).

Rolshausen, P., Úrbez-Torres, J. R \& Rooney-Latham, S. (2010). Evaluation of Pruning Wound Susceptibility and Protection Against Fungi Associated with Grapevine Trunk Diseases. Journal of Am. J. Enol. Vitic. 61 (1). P. 113-119.

Tribel', S. O; Get'man, M. V; Strigun, O. O; Kovalishina, G. M. \& Andrjushhenko, A. V. (2010). Metodolohiia otsiniuvannia stijkosti sortiv pshenytsi proty shkidnykiv i zbudnykiv khvorob [Ed.: S. O. Trybel']. Киї: Kolobih, 392 s. (in Ukrainian).

Zheldakova, R. A. \& Mjamin, V. E. (2006). Fitopatogennye mikroorganizmy. Minsk: BGU. 116 s. (in Russian). 